\title{
Evaluation and Prospect Identification in the Olive Field, Niger Delta Basin, Nigeria
}

\author{
Emina R, Obiadi II ${ }^{*}$ and Obiadi CM
}

Department of Geological Sciences, Nnamdi Azikiwe University, Awka, Nigeria

\begin{abstract}
The study area lies in the Greater Ughelli Depobelt of Niger Delta. Recently, a major focus within the Niger Delta is the rejuvenation of older fields (also called brown fields) and the identification of new prospects from these old fields. This study is focused on the evaluation of the Olive Field and the identification of new prospects within the field. Data used were; 3D seismic cube, four composite well logs and check shot. 3 dimension seismic, well log and structural interpretation were done to evaluate the petroleum potentials of the reservoirs using the petrel 2010 and the interactive petrophysic v.36 softwares. Well data were used in the identification of reservoirs and determination of petrophysical parameters and hydrocarbon presence. Four horizons that corresponded to selected well tops were mapped after well to seismic tie. Time and depth structural maps were created from the mapped horizons. Four Hydrocarbon bearing reservoirs within the depth range of $6743 \mathrm{ft}-9045 \mathrm{ft}$, having volume of shale (Vsh) ranging from $15.32 \%-29.06 \%$ were interpreted. The total porosity of the reservoirs ranges from $24.63 \%-34.01 \%$, while the effective porosity ranges from $17.26 \%-31.71 \%$, indicating the reservoirs have very good porosities. The ratio of the Net to Gross Thickness of the reservoirs ranges from $0.720-0.980$ while the water saturation values ranges from $19.87 \%-29.07 \%$. From the water saturation deductions, the hydrocarbon saturation ranges from $70.93 \%-78.86 \%$ of gas in the given reservoirs. Amplitude attribute extraction and analysis of the horizon maps was used in the identification of areas with hydrocarbon accumulations which are conformable with structures. The use of structural and attribute maps has aided the identification of prospects in the Olive Field. Therefore, it is recommended that wells be drilled to target the new prospects which will improve the hydrocarbon recovery in Olive Field.
\end{abstract}

Keywords: Olive; Delta; Reservoirs; Petroleum hydrocarbons

\section{Introduction}

The Olive Field is located within the Greater Ughelli Depobelt, Onshore Niger Delta, Nigeria (Figure 1). Recently, major focus within the Niger Delta has been directed to the rejuvenation of older fields and the identification of new prospects from these old fields. Studies on the Niger Delta, has shown that reservoirs in this Basin exhibit range of complexities in the sedimentological and petrophysical characteristics due to differences in hydrodynamic conditions prevalent in their depositional setting.

Reservoir characterization technology requires the integration of all available subsurface data such as well logs, check shot, core data, biostratigraphic data, and seismic data. These data are the result of measurement carried out by sophisticated instrumentations and processed using highly developed software [1]. The parameters characterized in a reservoir include structure (fold, fault, and fractures), internal architecture (homogeneity), petrophysical properties (porosity and permeability) and hydrocarbon properties (thermodynamics) [2].

Considering the increasing global demand for energy, the high cost of hydrocarbon production and the associated risk, more robust ways of evaluating and characterizing reservoirs is required to enhance the identification of new prospect and improve yield / rejuvenate older fields as its much cheaper and less risky than exploring in frontier / unknown areas [3]. Aizebeokhai and Olayinka established that reservoir heterogeneity and formation evaluation problems can make it difficult to characterize fluid distribution, estimate hydrocarbon in place and determine permeability. They suggested that the approach used in characterizing a reservoir should involve a combination of analysis of geological framework of the reservoir, hydrocarbon trapping components (stratigraphic and structural), formation evaluation and the calculation of volumetric hydrocarbon in place. Obiadi et al. generated horizon and structural maps of the subsurface geology of parts of the Niger Delta by interpreting seismic data [4]; and on the bases of structural closures identified leads in deeper horizons of producing fields [5]. Adetaye and Enikanselu extracted reflection attributes from subsurface maps and used it to map lateral boundaries of reservoirs [6]. Omoboriowo et al. used suit of geophysical well-logs for detailed petrophysical and well log sequence stratigraphic analysis in the Niger Delta. Their findings show that reservoirs vary in petrophysical properties due to differences in their environment of deposition. This paper is aimed at analysing and integrating seismic and well log data to aid reservoir characterization and prospect identification in the Olive Field, an old field in the Niger delta.

\section{Geology and tectonic setting of the Niger delta basin}

The tectonic framework of the continental margin along the West Coast of equatorial Africa is controlled by Cretaceous fracture zones which subdivide the margin into individual basins, and, in Nigeria, form the boundary faults of the Cretaceous Benue-Abakaliki trough. The trough represents a failed arm of a rift triple junction associated with the opening of the South Atlantic. In this region, rifting started in the Late Jurassic and persisted into the Middle Cretaceous [7]. In the region of the Niger Delta, rifting diminished altogether in the Late Cretaceous. After rifting ceased, gravity tectonics became the primary deformational process. Shale mobility induced internal deformation

"Corresponding author: Obiadi II, Department of Geological Sciences, Nnamdi Azikiwe University, Awka, Nigeria, E-mail: izuchukwuig@yahoo.com

Receive May 09, 2016; Accepted June 17, 2016; Published June 25, 2016

Citation: Emina R, Obiadi II, Obiadi CM (2016) Evaluation and Prospect Identification in the Olive Field, Niger Delta Basin, Nigeria. J Pet Environ Biotechnol 7: 284. doi:10.4172/2157-7463.1000284

Copyright: (C) 2016 Emina R, et al. This is an open-access article distributed under the terms of the Creative Commons Attribution License, which permits unrestricted use, distribution, and reproduction in any medium, provided the original author and source are credited. 


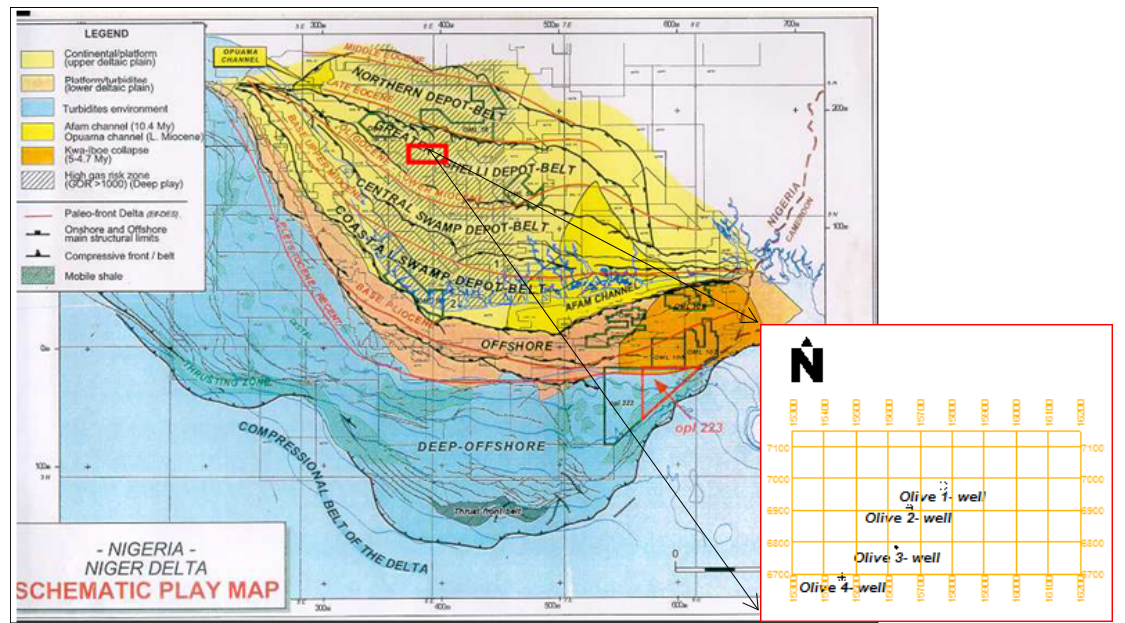

Figure 1: Geologic map of the Niger Delta showing depobelts and structural element, and the study area highlighted in red box. Insert is the seismic survey base map.

and occurred in response to two processes [8]. Firstly, shale diapirs formed from loading of poorly compacted, over-pressured, prodelta and delta-slope clays (Akata Formation) by the higher density deltafront sands (Agbada Formation.); and secondly, slope instability occurred due to a lack of lateral, basinward support for the undercompacted delta-slope clays. For any given depobelt, gravity tectonics were completed before deposition of the Benin Formation and are expressed in complex structures, including shale diapirs, roll-over anticlines, collapsed growth fault crests, back-to-back features, and steeply dipping, closely spaced flank faults [9]. These faults mostly offset different parts of the Agbada Formation and flatten into detachment planes near the top of the Akata Formation. Three lithostratigraphic units are distinguished in the Tertiary Niger Delta. The basal Akata Formation which is predominantly marine prodelta shale is overlain by the paralic sand/shale sequence of the Agbada Formation. The topmost section is the continental upper deltaic plain sands - the Benin Formation. Virtually all the hydrocarbon accumulations in the Niger Delta occur in the sands and sandstones of Agbada Formation where they are trapped by rollover anticlines related to growth fault development $[10,11]$.

\section{Data Availability and Methodology}

Data used in the study include wireline logs (Gamma ray, Sonic, Density, Resistivity and Neutron logs) from four (4) wells in the field; check shot data and 3-D seismic volume of the field. Software resources used include Petrel and IP softwares. The study was carried out in two interactive and interrelated stages - Well log analysis / Formation Evaluation and Seismic data interpretation (Figure 2).

\section{Well log analysis/formation evaluation}

Reservoirs were identified and correlated across the wells using Gamma and Resistivity logs. The gamma ray log was used in identifying the lithology penetrated by the wells. A shale base line was established, and deflection of the log signature to the right of the shale base line was interpreted as shale (non-reservoir lithology) while deflection to the left of the shale base line was interpreted as sandstone (reservoir lithology). For the resistivity log, deflections to the left were interpreted as low resistivity (or high conductivity). Saline water bearing formations are characterised by low resistivity while hydrocarbon bearing intervals

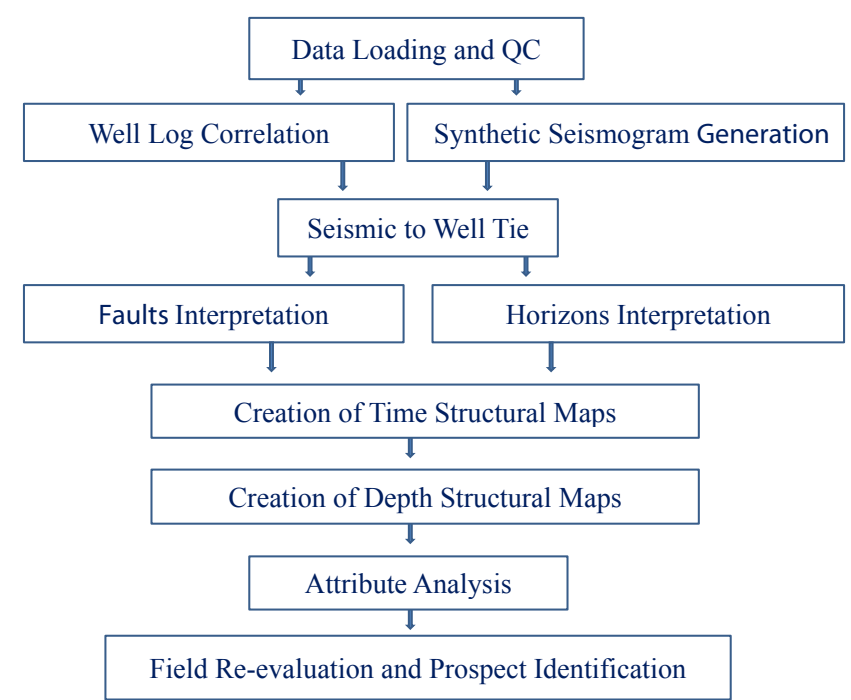

Figure 2: Generalized workflow chart for seismic data interpretation.

(reservoirs) have high resistivity. Having identified the reservoirs, the Net-to-Gross ratio was calculated.

Hydrocarbon typing was done using the sonic / resistivity logs comparison method. It is best applied as an overlay technique and provides a quick look identification of hydrocarbon bearing zones and type. In water bearing intervals, the lateral deflections (log signatures) due to porosity changes on a resistivity and sonic log are very similar in magnitude, when displayed on a standard scale. If the logs are adjusted to overlay in water bearing zones, hydrocarbon bearing zones will be evident by a deflection of the resistivity log to the right. Gas bearing zones can be identified by a tendency for the sonic to shift to the left due to the slowing of the compressional wave. Thus in gas bearing intervals, the separation between the sonic and resistivity will be greater than in oil bearing intervals.

Volume of Shale $\mathrm{V}_{\text {Sh }}$ was estimated from the Gamma Ray Log using the equation:

$$
\mathrm{V}_{\text {Sh }}=\frac{G R_{\text {log }}-G R_{\text {clean }}}{G R_{\text {Shale }}-G R_{\text {Clean }}}
$$


Where

$\mathrm{GR}_{\log }=$ Gamma Ray log reading for formation interval

$\mathrm{GR}_{\text {Shale }}=$ Maximum Gamma Ray log reading (shale)

$\mathrm{GR}_{\text {Clean }}=$ Minimum Gamma Ray log reading (Clean sand)

Porosity $\Phi$ was estimation in the mapped reservoirs using the Density Log reading and the equation:

$$
\Phi=\frac{\rho_{m a}-\rho_{b}}{\rho_{m a}-\rho_{\text {fluid }}}
$$

Where:

$\rho_{m a}=$ Rock matrix density

$\rho_{\mathrm{b}}=$ Measured density

$\rho_{\text {fluid }}=$ Flushed zone measured density

Effective porosity (interconnected pore spaces) was also estimated from Density Log readings and the equation:

$$
\Phi_{\mathrm{e}}=\frac{\rho_{m a}-\rho_{b}}{\rho_{m a}-\rho_{\text {fluid }}}-\mathrm{V}_{\mathrm{Sh}}\left\{\frac{\rho_{m a}-\rho_{\text {Sh }}}{\rho_{m a}-\rho_{\text {fluid }}}\right\}
$$

Where:

\section{$\rho_{s h}=$ measured shale density}

Water saturation $S_{w}$ of the un-invaded was estimated using the Resistivity Log reading and the equation:

$$
S_{w}^{2}=\frac{R_{0}}{R_{T}}
$$

Where:

$$
\begin{aligned}
& \mathrm{R}_{0}=\text { Resistivity of formation at } 100 \% \text { water saturation } \\
& \mathrm{R}_{\mathrm{T}}=\text { True formation resistivity }
\end{aligned}
$$

The hydrocarbon saturation $\mathrm{S}_{\mathrm{hy}}$ was estimated from the calculated water saturation thus:

$$
\mathrm{S}_{\text {hy }}=1-\mathrm{S}_{\mathrm{w}} \text { or } \mathrm{S}_{\mathrm{hy}} \%=100-\mathrm{S}_{\mathrm{w}} \%
$$

\section{Seismic data interpretation}

Synthetic seismogram was generated using the well logs (Figure 3), horizons picked at the top of the mapped reservoirs and tied to the seismic data (Figure 4). A good tie was obtained between the synthetic seismogram and the seismic data. Faults defined by abrupt termination and dislocation of reflection pattern were identified and interpreted all through the seismic volume. The picked horizons were also mapped all through the seismic volume. Horizon/structural maps were generated for the horizons mapped, and using the check-shot data, converted from time to depth. Seismic (amplitude) attribute was extracted from the horizon/structural maps. Prospects were then identified from the generated maps and seismic attributes.

\section{Result and Discussion}

Well $\log$ analysis resulted in the identification of reservoirs penetrated by wells in the study area. These reservoirs were identified on the basis of relatively low gamma ray values and corresponding high resistivity reading. The reservoirs, designated Reservoir 1-4, were correlated across the well from the most distal (landwards) to the most proximal (seaward) well (Figure 5).

Reservoir 1 was penetrated by all four well. It is characterized by relatively high resistivity values and signature of the sonic log within this reservoir interval shows its hydrocarbon type to be gas (Figure 6). Estimates of petrophysical parameters computed form different logs from the well are summarised in Table 1. Reservoir 2 also was penetrated by all four wells in the Olive field. The thickness of this reservoir increases basinwards suggesting incision from a lowstand. The well log signature shows it to be hydrocarbon bearing and the hydrocarbon type to be gas. Reservoir 3 was identified in wells 1 and 2 but did now appear in wells 3 and 4 . Hydrocarbon type is interpreted to be gas also. Reservoir 4 was penetrated by wells 1, 2 and 4, and the hydrocarbon type is gas.

Results of the well $\log /$ petrophysical analysis show that the reservoir quality decreases in the basinward (distal) direction. The net-

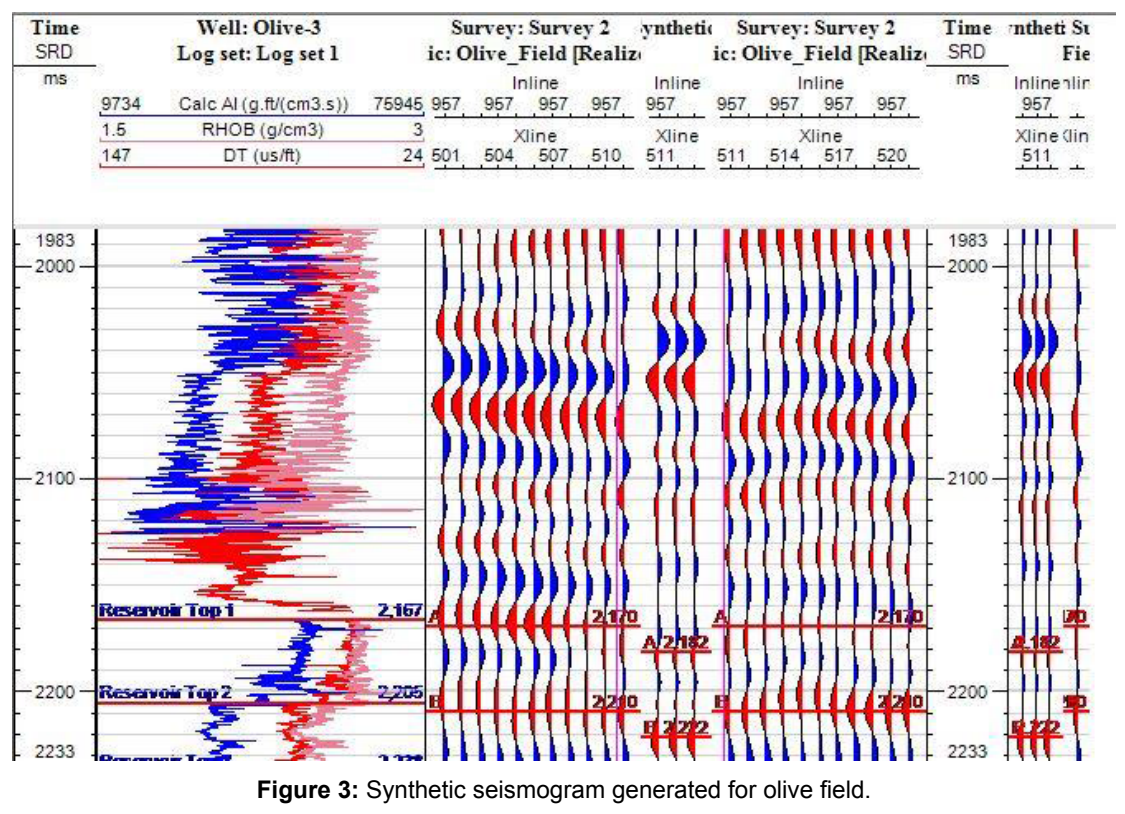


Citation: Emina R, Obiadi II, Obiadi CM (2016) Evaluation and Prospect Identification in the Olive Field, Niger Delta Basin, Nigeria. J Pet Environ Biotechnol 7: 284. doi:10.4172/2157-7463.1000284

Page 4 of 7

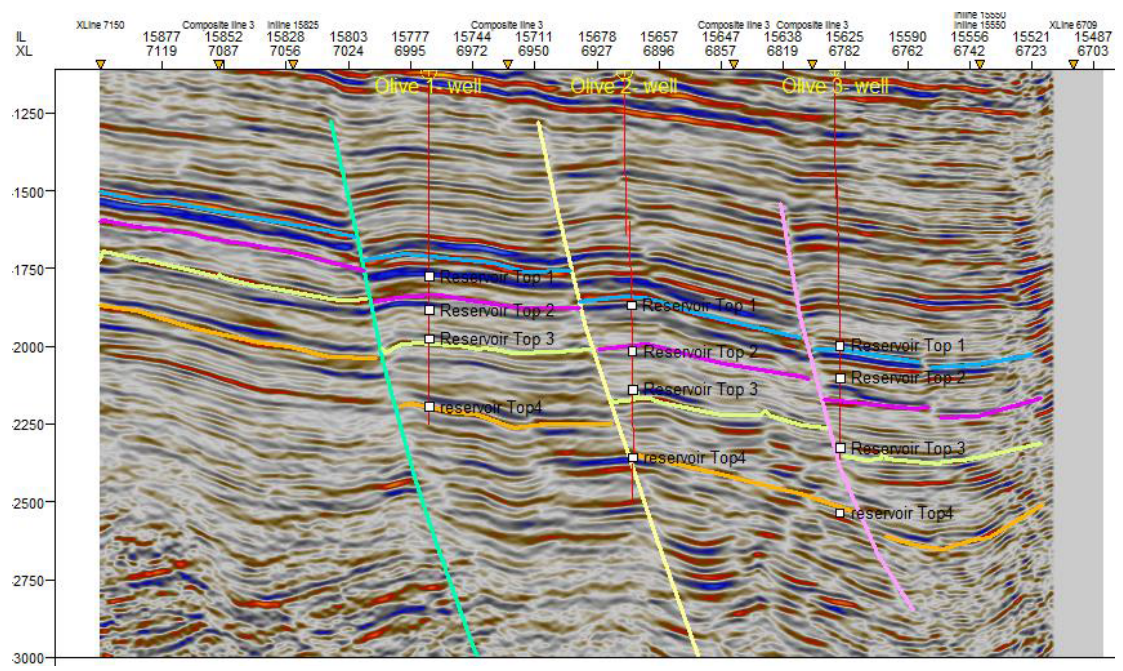

Figure 4: Seismic-to-well-tie showing well trace, picked horizon tops and some faults.

Basinward direction $\longrightarrow$

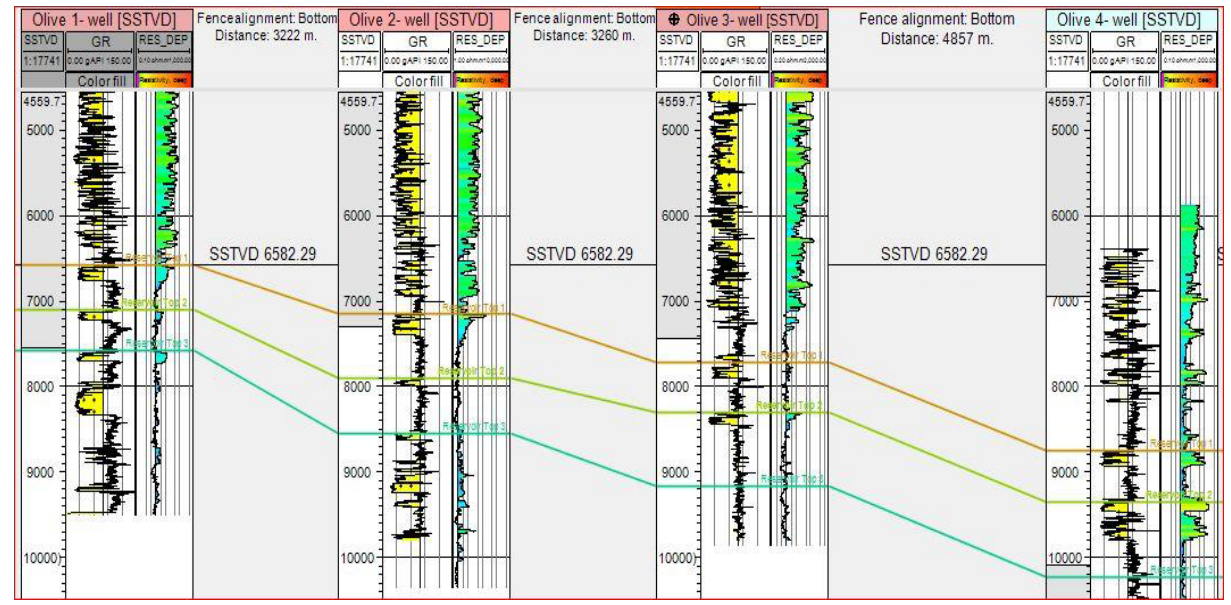

Figure 5: Well log correlation panel showing spatial distribution of mapped reservoirs.

\begin{tabular}{|c|c|c|c|c|}
\hline \multirow[t]{2}{*}{ Petro-physical Parameter } & \multicolumn{4}{|c|}{ Estimated Values } \\
\hline & Olive Well 1 & Olive Well 2 & Olive Well 3 & Olive Well 4 \\
\hline Reservoir 1 interval & $6743-6915 \mathrm{ft}$ & $7310-7549 \mathrm{ft}$ & $8454-8599 \mathrm{ft}$ & $8900-9045 \mathrm{ft}$ \\
\hline Hydrocarbon type & Gas & Gas & Gas & Gas \\
\hline Gross Thickness & $172 \mathrm{ft}$ & $239 \mathrm{ft}$ & $144.50 \mathrm{ft}$ & $155.5 \mathrm{ft}$ \\
\hline Net thickness & $168 \mathrm{ft}$ & $213 \mathrm{ft}$ & $104 \mathrm{ft}$ & $125 \mathrm{ft}$ \\
\hline Net/Gross & 0.980 & 0.89 & 0.72 & 0.81 \\
\hline Volume of shale/clay & 0.153 or $15.33 \%$ & 0.17 or $17.36 \%$ & 0.29 or $29.06 \%$ & 0.23 or $22.67 \%$ \\
\hline Total porosity & 0.34 or $34.01 \%$ & 0.31 or $30.79 \%$ & 0.26 or $25.62 \%$ & 0.25 or $24.63 \%$ \\
\hline Effective porosity & 0.32 or $32.00 \%$ & 0.28 or $28.18 \%$ & 0.21 or $21.26 \%$ & 0.17 or $17.26 \%$ \\
\hline Water saturation & 0.19 or $19.8 \%$ & 0.22 or $21.58 \%$ & 0.29 or $29.07 \%$ & 0.21 or $21.14 \%$ \\
\hline Hydrocarbon saturation & 0.80 or $80.13 \%$ & 0.78 or $78.42 \%$ & 0.71 or $70.93 \%$ & 0.79 or $78.86 \%$ \\
\hline
\end{tabular}

Table 1: Summary of some estimated petro-physical parameters.

to-gross ratio decreased from 0.98 in the most proximal well (Olive well 1) to 0.81 in the most distal well (Olive well 4). This is also seen in the Volume of Shall which increased from $15.33 \%$ in Olive Well 1 to $22.67 \%$ in Olive Well 4 . A very important property of reservoir is effective porosity, and this too is estimated to have decreased from a value of $32 \%$ for Olive Well 1 to $17.26 \%$ in Olive Well 4 . Hydrocarbon saturation has also followed similar trend with a value of $80.13 \%$ in the most proximal well to 78.86 in the most distal well. Corresponding reservoir intervals in all the wells are seen to be penetrated at greater depths from Olive Well 1 to Olive Well 4. This is typical of the Niger Delta Basin and suggestive of progradation. Hydrocarbon typing showed that all the reservoirs contain gas. 
Citation: Emina R, Obiadi II, Obiadi CM (2016) Evaluation and Prospect Identification in the Olive Field, Niger Delta Basin, Nigeria. J Pet Environ Biotechnol 7: 284. doi:10.4172/2157-7463.1000284

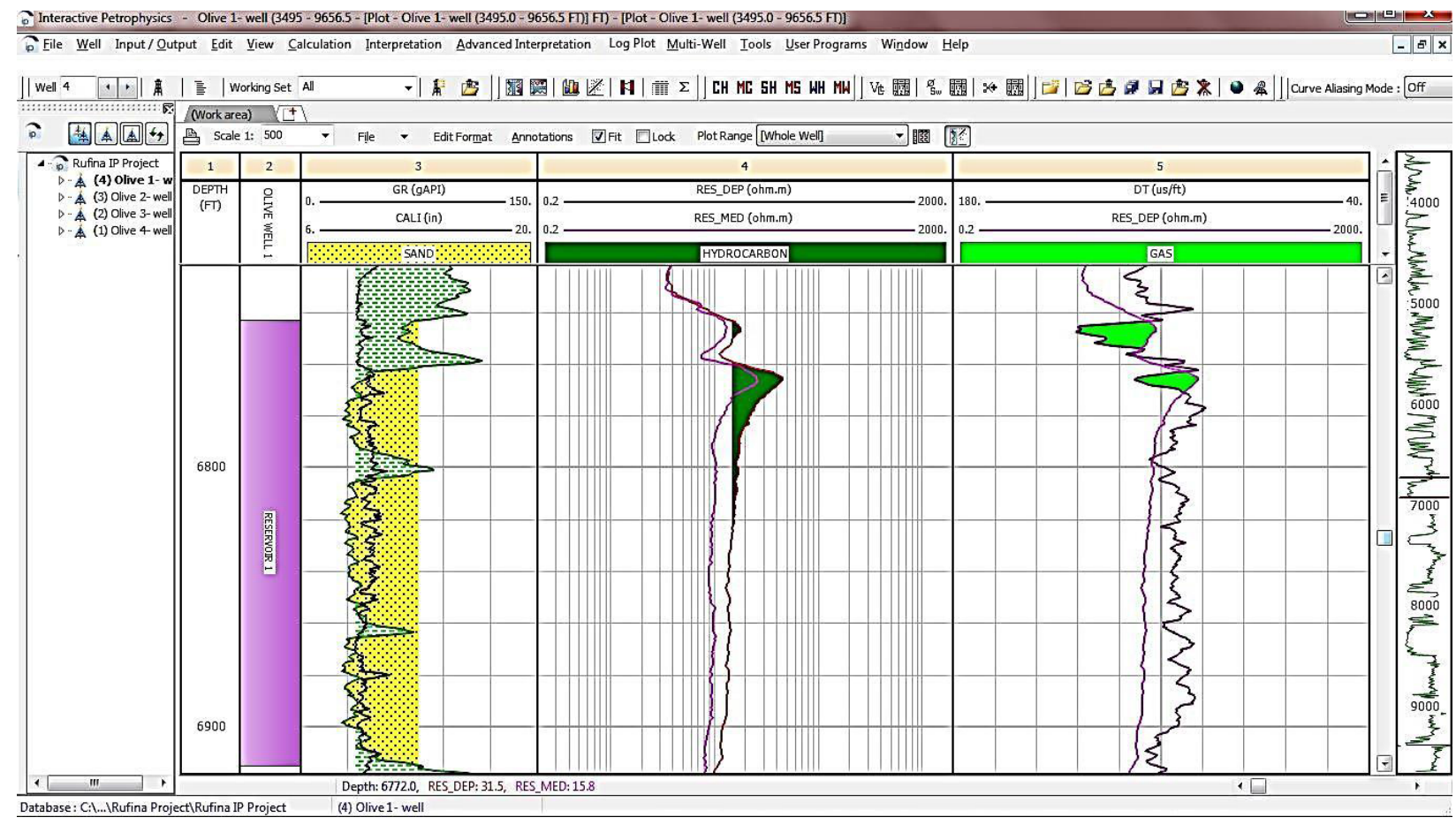

Figure 6: Hydrocarbon typing panel indicating gas in reservoir 1 in olive well 1.

Several faults were picked in the study area (Figure 7). Most of the faults are synthetic growth faults characterised by fault surfaces that are concave in the basinward direction, while some are antithetic and terminate against the synthetic faults. Four horizons corresponding to the tops of the reservoirs mapped during the well log analysis were tied to the seismic volume with the aid of the synthetic seismogram and picked all through the seismic volume to produce Time Structural Maps for all the mapped horizons (Figure 8). With the aid of the velocity data, the Time Structural Map was converted to Depth Structural Map (Figure 9).

The structural maps displayed in time and depths are very similar suggesting good horizon interpretation. The structural maps showed that the field is compartmentalized into several blocks by faults, and these faults and fault blocks formed closures (traps) for hydrocarbon accumulation. The four wells drilled in the field targeted these traps (Figures 7 and 8 ).

Seismic amplitude attribute map generated from the four horizon maps showed that the fault closures are characterised by high amplitude (Figure 9). Since the horizons mark the top of reservoirs, the high amplitude recorded on the horizons indicates the presence of hydrocarbon within the mapped reservoirs and supports the results of the well $\log$ analysis.

\section{Prospect Identification}

The Akata Shale source rock, which are thick marine shales deposited at the base of the delta in an oxygen deficient environment is present in large volume beneath the Agbada Formation (main reservoir unit) and is at least volumetrically sufficient to generate enough hydrocarbon for a world class province like the Niger Delta [4,11]. Total Organic Carbon TOC values for the Akata source rock ranges from $0.4 \%-14.4 \%$ [12]. The sandstone reservoir units of the overlying

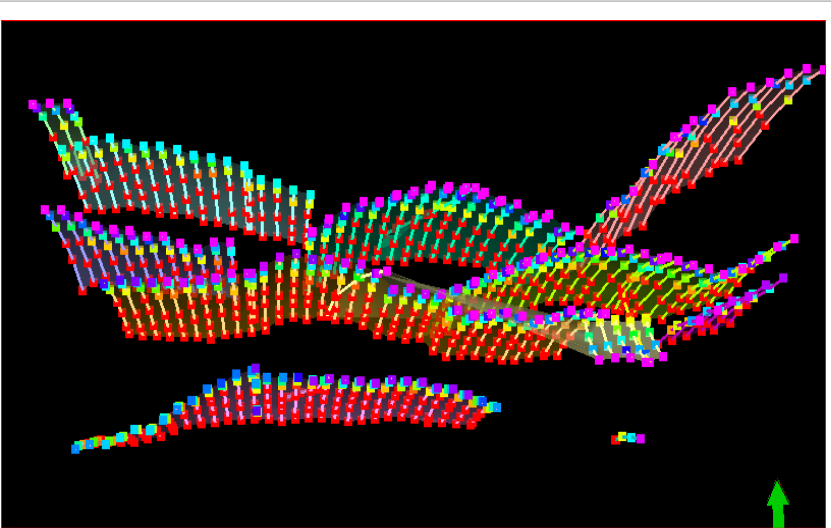

Figure 7a: Interpreted fault sticks in 3D view.
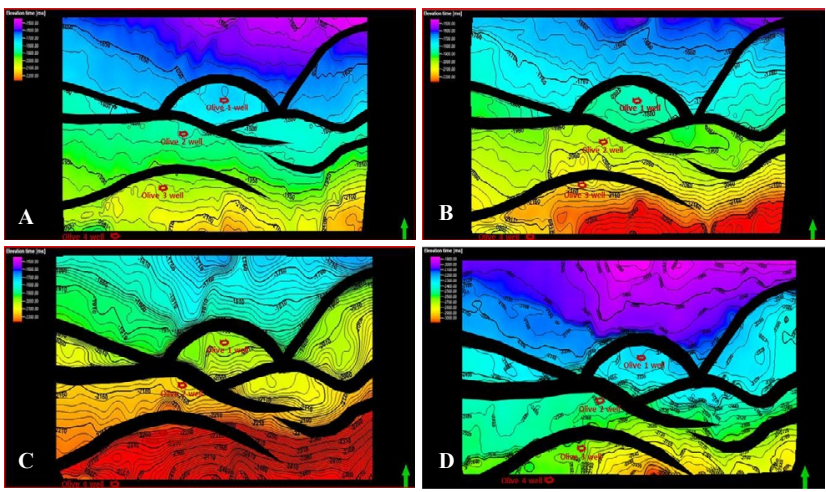

Figure 7b: Time Structural Maps of Reservoir Top 1 (A), Reservoir Top 2 (B) Reservoir Top 3 (C) and Reservoir Top 4 (D) with well positions. 

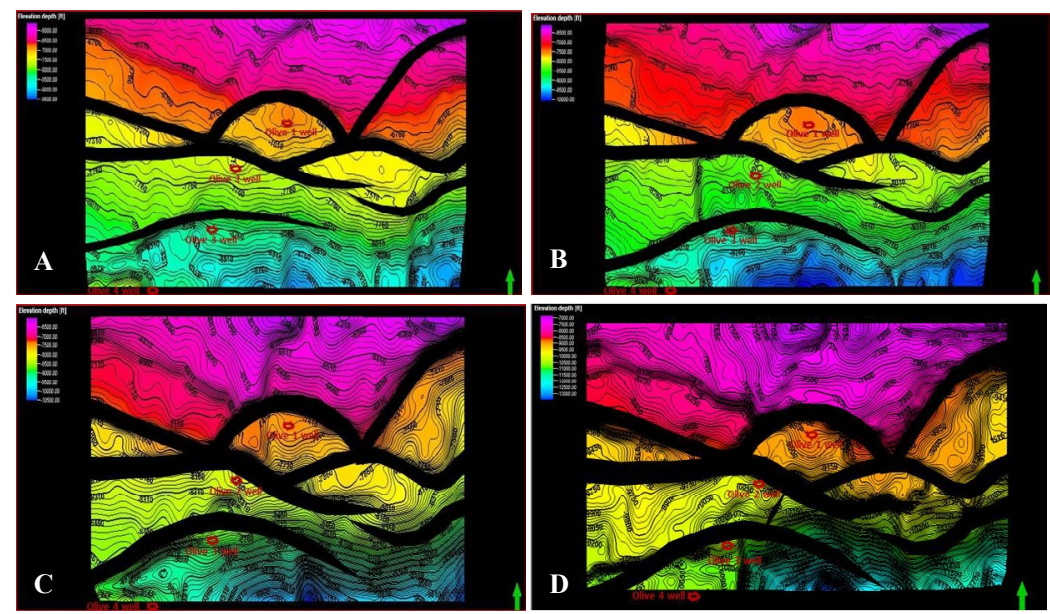

Figure 8: Depth structural maps of Reservoir Top 1 (A), Reservoir Top 2 (B), Reservoir Top 3 (C) and Reservoir Top 4 (D) with well positions.

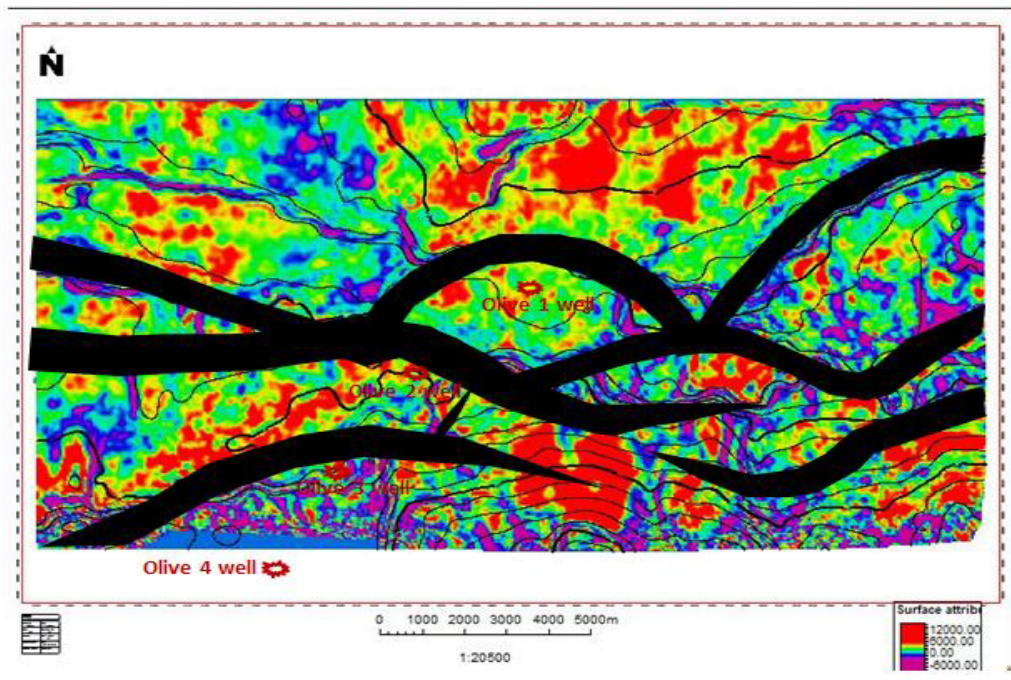

Figure 9: Amplitude attribute map of Reservoir Top 4 showing faults closures characterised by high amplitudes and well drilled to target them.

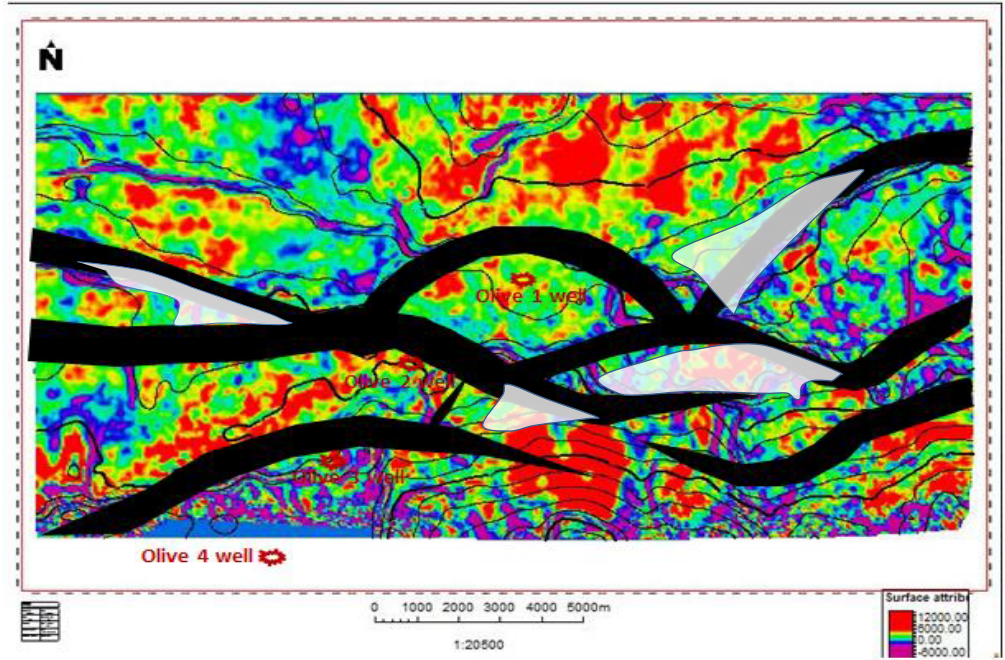

Figure 10: Structural map of Reservoir Top 4 with overlay of amplitude attribute showing four identified prospect (highlighted in white). 
Citation: Emina R, Obiadi II, Obiadi CM (2016) Evaluation and Prospect Identification in the Olive Field, Niger Delta Basin, Nigeria. J Pet Environ Biotechnol 7: 284. doi:10.4172/2157-7463.1000284

Agbada Formation are also widespread over the basin in. Structural interpretation shows that the Olive Field is highly faulted with several fault block forming closure and potential traps for hydrocarbon entrapment and accumulation. The four well drilled in the field are all vertical wells and targeted some of these structural traps. However, from the structural maps produced from the structural interpretation of the seismic volume data showed the presence of other structural closures/traps which has not been drilled into. The amplitude attribute map extracted over these untested structural closures showed the occurrence of high amplitude over them, leading to the identification of four (4) prospects in the Olive Field (Figure 10). These prospects are characterised by closures against two branching faults and relatively high amplitude (bright spot). It is recommended that these prospects be tested as this will improve the viability of the Olive Field.

\section{Conclusion}

Evaluation of the Olive Field, Niger Delta basin was done using well $\log$ and seismic data volume. Well $\log$ / petrophysical analysis was carried out using log suites from four well. Four reservoirs at different intervals in the well logs were mapped in the field. The petrophysical parameters of the reservoirs showed a general decrease in quality in the basin ward direction from the most proximal well (Olive Well 1) to the most distal well (Olive Well 4). Hydrocarbon typing showed that the reservoirs all contain gas.

Seismic interpretation showed that the field is highly faulted with the faults forming structures for hydrocarbon entrapment and accumulation. Four of these trapping structures have been targeted and exploited by the four wells drilled in the field. Seismic amplitude attribute maps extracted from the tops of the mapped reservoirs showed that the reservoirs are characterised by relatively high amplitudes (bright spots) in areas enclosed by the structural traps. This led to the identification of four (4) prospects within the Olive Field. It is recommended that these prospects be tested to improve the viability of the field.

\section{References}

1. Jarvis K (2006) Integrating well and seismic data for reservoir characterization: Risks and Rewards. AESG 1: 1-4.

2. Cosentino $L$ (2001) Integrated reservoir studies. Technip.

3. Aizebeokhai AP, Olayinka I (2011) Structural and stratigraphic mapping of Em field, offshore Niger Delta. J Geol Mini Rese 3: 25-38.

4. Obiadi II, Ozumba BM, PL Osterloff (2012) Sequence stratigraphy and hydrocarbon distribution in parts of the eastern central swamp depobelt, Niger Delta, Nigeria. NAPE Bulletin 24: 43-51.

5. Adetoye TO, Enikanselu PA (2009) Hydrocarbon reservoir mapping and volumetric analysis using seismic and bolehole data over extreme field, South Western Niger Delta. Ocean Journal of Applied Sciences 2: 429-431.

6. Omoboriowo AO, Chiaghanam OI, Chiadikobi KC, Oluwajana OA, SoronnadiOnoniwu et al. (2012) Reservoir characterization of Konga Field, Onshore Niger Delta, Southern Nigeria. Int. J Sci. Emerging Tech 3: 19-31.

7. Lehner P, De Ruiter PAC (1977) Structural history of Atlantic Margin of Africa AAPG Bulletin 61: 961-981.

8. Kulke H (1994) Regional Petroleum Geology of the World. Part II: Africa America, Australia and Antarctica: Berlin Borntraeger G 21-22: 143-172.

9. Evamy BD, Haremboure J, Kamerling P, Molloy FA, Rowland PH (1978) Hydrocarbon habitat of Tertiary Niger Delta. AAPG Bulletin 63: 1-39.

10. Ekweozor CM, Daukoru ED (1994) Northern delta depobelt portion of the Akata-Agbada (!) petroleum system, Niger Delta, Nigeria pp: 599-613.

11. Michele LW, Ronald RC, Michael EB (1999) The Niger Delta Petroleum System Niger Delta Province, Nigeria Cameroon, and Equatorial Guinea, Africa.

12. Ekweozor CM, Okoye NV (1980) Petroleum source-bed evaluation of Tertiary Niger Delta. AAPG Bulletin 64: 1251-1259. 